\title{
On the concept of humanistic base texts
}

\author{
Linnart Mäll \\ P.O. Box 414, 50002 Tartu, Estonia \\ e-mail: ero@hot.ee
}

\begin{abstract}
I elaborated the concept of humanistic base texts when I was translating Indian and Chinese classical texts into Estonian. At present, I would classify as such the following works: "Bhagavadgitāa", a part of Buddhist texts, "Lunyu" by Confucius and the Gospels according to Luke, Matthew and Mark, to mention only a few. This article gives a general survey of the concept, to be specified in the papers to follow.
\end{abstract}

The shifts in social life that occur with the passing of time, or history, can be described and explicated from various angles. First and foremost, the choice of the latter depends on which phenomena and tendencies the describer or explicator considers as decisive or, even, motive powers. Thus, for example, changes in production and exchange or, in other words, in economic life, have been regarded as such, or else the events within or between countries (for instance, in diplomacy or battlefields), which is to say, in politics. Likewise, the alterations, renewals and decay of mythological, religious, philosophical, artistic and ideological ideas, or changes in the spiritual world, have also been held responsible, as have, indeed, many other things. The present author regards humanistic base texts as the greatest influencing factor in the history of the last couple of millennia.

Despite their major impact, the number of humanistic base texts is not really large. They were created, or they appeared or took shape (the use of several words above refers to the complex nature of the formation process of the texts; from now on, only one of those will be used, 'to take shape') in various parts of the Old World in a definite period of time. This is characterized by the distinct formation of the 
new social dimension which had started to evolve much earlier, but was left unrecognized for a long time, denoted by different words in different places back then, but which can at present be termed, in the most general sense, as culture.

It must have become obvious at that period that mankind was more than just a part of the surrounding nature, and that the human being more than merely a member of the tribe or people or polis or state, and the transmitter of its traditions and mythological and religious beliefs. The burden of the personal existence must have struck one for the first time at approximately the same time, which found expression in the questions addressed to oneself and other people: "How to be?", "Why to be?", "What to do?", "How to improve or change myself or, how to become different or new?" All these questions presuppose an awareness of the sense of duty and responsibility, and I would like to add at this point that the so-called existential questions in the manner of "To be or not to be?" were probably not popular back then.

Although in the absolute time scale this period and, as a result, the formation of humanistic texts do not exactly coincide by regions, one could still maintain as a generalization that it took place between the 6 th century $\mathrm{BC}$ and the $2^{\text {nd }}$ century $\mathrm{AD}$, while some of the texts have taken their final shape even later.

We shall now attempt to sum up the meaning of this notion. The word 'base text' refers, logically enough, to the text that has been a basis for other texts; thus we have a text here that over the ages has functioned as a text generator. A genuine base text has the ability to give rise to an indefinite number of new texts in an indefinite period of time which do not have to be put down in writing but may, as indeed they mostly do, exist either in the form of oral speech or discussion or even as a speculative act (deliberation, reflection, contemplation, meditation).

A humanistic base text has a specific tendency, expressed by the word 'humanistic'. In English, the semantic range of this word has been conveyed by mainly two equivalents: 'humane' and 'human', in the sense of being 'characteristic of man'. The semantic range of these both, as is generally known, is rather vague. Thus, to be more specific, a 'humanistic base text' is a base text that on the one hand is characterized by elevating man as such (in other words, as a species and an individual) to the central and determining phenomenon of existence, on the other hand, by an emphasis on such 'humane' qualities as dig- 
nity, philanthropy, compassion, non-violence, responsibility, sense of duty, respect, etc. in human relations.

Although each humanistic base text has evolved within the context of a definite culture, reflecting the latter's influence both in its form and content to such an extent that at first glance it may seem difficult, if not entirely impossible, to find a common denominator for them, there are still enough similarities and common features that allow us to do so, relating to both the formation process and structure of the texts (A) and the doctrines they contain (B), as well as the direct and indirect impact they make $(\mathrm{C})$. We shall now present the most essential ones:

A1. Humanistic base texts evolved in a relatively developed cultural environment, characterized by the existence of the art of writing and a generally accepted and, in some cases, the sole religious and mythological thought system, as well as by an aspiration to establish, in one form or the other, a social hierarchy. At the same time, we can detect a tendency to reinterpret the existing and to present new ideas and doctrines.

A2. These texts have nominal authors, referred to by the same texts and the tradition based on them.

A3. These texts present a definite Teaching. This Teaching has been given through the mouth of a definite Teacher, who has a definite mission to preach it. The texts describe, to a greater or lesser extent, the life story of the Teacher.

A4. Although the Teachers must have certainly been literate, due to their origin and education, they preached their Teachings by word of mouth, so that those became fixed in writing only later by their immediate disciples or the inheritors of the teaching tradition. Because the editing process of the texts continued also after that, they acquired their final finished (canonical) form later still.

A5. Despite all this, a certain authorial idiosyncrasy can be detected in all humanistic texts, embracing both descriptions and the way the Teaching is presented. This and other characteristic features of the humanistic base texts have now and again given rise to opinions that the actual proponents of the Teaching are the nominal authors, or the latter are entirely unknown, and that the Teacher is altogether a fiction or a generalized literary figure.

A6. The Teacher is depicted as an unusual person in some way, to whom extraordinary, supernatural and downright divine qualities are ascribed. 
A7. Yet also the human features and even weaknesses of the Teachers have been emphasized in the humanistic base texts. They all feel sad at times when they are not understood and they often doubt the expediency of their mission. They do not consider themselves to be unique and superior to other people. Instead, they think and expect that the others should follow them and become like them. This is particularly true of their relations with their disciples, among whom there are always some that are convinced that they surpass the Teacher so much that it gives them even the right to betray.

B1. The Teaching presented by any humanistic base text is formally, content-wise and also terminologically related to a certain cultural environment, within which it evolved. According to the Teachers themselves, their doctrines are not entirely original, having been preached in one form or other earlier as well.

B2. Yet the novelty of the message of all humanistic texts was quite literally revolutionary, and not just because the Teachings that were proclaimed differed radically from the existing ones, but also partly due to the fact that the situation was right for their emergence.

B3. As pointed out earlier on, the most significant aspect of these Teachings is their humanism - their humanity and humanness. The main objective of humanistic teachings is to show to man the sense of his existence and what his possibilities and duties are, not only in the physical world, but also in the social and cultural situation at the given moment at the given place; to make the man understand that he as a member of mankind and as a definite personality (but not as ego) is something unique in the world, which is why he can and even must, bearing full responsibility, act in a novel way.

B4. The uniqueness of man as a member of mankind is manifested in that gods and other supernatural creatures and phenomena are no longer unequivocally placed above man, but that they are considered equal to him in many ways and sometimes even lower. A god may acquire human shape, appear as a human being, and man may become a god.

B5. The uniqueness of man as a personality is manifested above all in the emphasis of the fact that it is him as a definite person that has been chosen to carry out the Teaching.

B6. This also means that man as an individual has an opportunity to improve himself, to change himself, to become new. Man is not destined to remain the same or to retain his former self. Instead, he has 
the freedom to choose between remaining the same and becoming new, as well as the freedom of choosing between the various possibilities and means or ways of becoming new.

B7. In all humanistic base texts, the emphasis has been laid on describing the path or the process of man's renewal. The explication of the path has been preceded by the analysis of the initial situation, that the man inevitably has to proceed from, as well as the more or less exact formulation of where the man will end up.

B8. Principally everybody can renew himself, and it does not depend on one's origin or status in the social hierarchy, but above all on how the Teaching or, to put it differently - a new cultural paradigm - has been adopted.

B9. This means that man is culture-centered from the point of view of humanistic base texts: not only does he depend on the current state of culture and recreate the culture, but he also possesses an ability to create and bring to culture utterly new phenomena, and even a completely new cultural whole, something that the Teachers themselves have quite unequivocally accomplished.

B10. At the same time man has to understand that he himself is not the creator of culture, for the process of creation only takes place through him, that is, it is the culture that functions through him. The man must understand that the ego that thinks that it has its own thoughts and performs its own acts does not, in fact, exist, so that it has either to be done away with or at least subjected to something that in the given culture is regarded as greater or higher.

B11. The reason for the emergence of ego is the self-protective endeavour of the individual, caused by the fact that man originates from nature, or, in other words, from the animal world. The humanistic base texts accept this fact to a greater or lesser extent, while implying at the same time that the focus of human existence should be located somewhere else, on a cultural level, which also means that the natural nature should be replaced by the cultural one.

B12. It follows from the above that the relations based on physical descent ( i.e. genetic information) should not be as important as the culturally determined relations (i.e. cultural information).

B13. This in turn allows us to say that the transmission of cultural information is more important than that of the genetic information. All humanistic base texts view the Teacher-disciple relationship as more significant than the parent-child or kinship relations. Studying and 
passing on the teaching are considered more valuable than procreation and taking care of physical children.

B14. At the same time, the humanistic base texts stress the need for the man to remain humane, meaning that he must treat if not everything that is alive, then at least human beings, with compassion and love.

B15. Compassion and love are notions that have many meanings and that can and may be interpreted rather deliberately. One needs sense to grasp their truly humane significance and to know and employ them as such. Common sense, consciousness, comprehension, understanding (i.e. intellectuality) - these are among the most essential concepts in humanistic base texts, the development of intellectual capacities being one of the principal means, as well as objectives, in the process of human renewal (or attaining the higher state of consciousness or repentance).

B16. To sum it all up - the process of becoming a new man or humanization actually means becoming a cultural man. The ideal, however, is not one-sided (specialized) culturalization but a total cultural immersion or absolute culturalization that from the point of view of humanistic base texts means that the natural animalistic or brutal human being has become a superman, saint, blessed, elevated, perfect, Buddha, bodhisattva, son of God, god etc. - the name depends on the specific character of the vocabulary of a definite cultural tradition.

$\mathrm{C} 1$. The dialogue between the base texts and background cultural environment began already at the first stage of their formation, at the time when the Teacher himself pronounced his Teachings either as sermons or instructions meant for one or another concrete person. Their impact was quite slight at first, becoming manifest mainly in the relatively limited circle of disciples. But their radical difference from the dominant or generally accepted ideology inevitably led to conflicts, which were often accompanied with severe repressions.

C2. As time passed, their impact gradually increased, reaching a truly explosive effect after the formation of canonical texts.

C3. Although one cannot detect the direct tendency in the humanistic base texts themselves, several religious, philosophical and other doctrines were formed on the basis of those, as well as certain institutions that often claimed the exclusive rights of interpreting these texts. In case such institutions managed to attain the dominating position in the society, the humanistic essence of the Teachings has been consid- 
erably reduced in the accepted interpretations at the expense of the dominant background system either in the period of the formation of the text or the emergence of the given interpretation.

$\mathrm{C} 4$. At the same time we should not underestimate the role of these institutions in spreading both the humanistic base texts, as well as the humanistic ideas, due to which their impact has reached global dimensions by today.

C5. By way of conclusion, let us maintain that even though in the course of history downright human-hating and ego-cult based teachings have been preached under the name of humanism, the direct and indirect impact of humanistic base texts has still been of cardinal importance in the ever-growing influence of humanistic ideas on the development of human society.

\section{О конщепции базовых гуманистических текстов}

С точки зрения данной концепции, базовые гуманистические тексты оказали определяюшее влияние на ход истории последних двух тысячелетий. Эти не столь многочисленные тексты сложились в разных регионах Древнего мира (в Китае, Индии, на Ближнем Востоке) в определенный исторический период, который можно, несколько обобшая, ограничить промежутком от -IV до +II вв.

Понятие "базовый текст" означает текст-генератор, который способен служить основой все новых текстов. У гуманистических базовых текстов особая направленность, выраженная словом "гуманистический". Их характеризует, с одной стороны, возвышение человека как такового (вида и отдельной личности) в качестве главного и определяющего явления бытия, с другой стороны, подчеркивание таких “человеческих" качеств как достоинство, любовь к человеку, сострадание, отказ от насилия, чувство ответственности и долга, почтительность и т.д.

Хотя любой гуманистический текст сформировался в контексте своей культуры, влияние которой отразилось в особенностях его содержания и формы, эти тексты достаточно сходны и имеют много обших черт. Эти сходства затрагивают в основном три аспекта: (А) процесс формирования и строение текстов, (Б) изложенные в них учения, (B) их непосредственное и опосредованное влияние.

(A) Все эти тексты излагают определенное Учение и исходят от определенного Учителя. Учителя проповедовали свое учение устно, оно было записано учениками и последователями и, наконец, в 
длительном процессе редактирования приобрело каноническую форму.

(Б) Учение каждого гуманистического базового текста связано по форме, содержанию и терминологии с определенной культурной средой, в которой он сложился. В то же время человек, с точки зрения базовых гуманистических текстов не только зависит от состояния культуры в данный момент и не является липњ воспроизводителем культуры, а прежде всего ее создателем. Цель базовых гуманистических текстов - показать человеку смысл его существования и его возможности и задачи не только в физическом мире, но и в сложившейся в данное время и в данном месте общественной и культурной ситуации; объяснить человеку, что он, как представитель человеческого рода и конкретная личность (но не эго), неповторим и поэтому может и должен действовать с полной ответственностыю.

(В) В диалоге базовых гуманистических текстов с фоновым культурным окружением их влияние в обществе начало расти, особенно после того, как сформировались канонические тексты. На их основе возникли религиозные, философские и другие учения, но и институции, которые часто пытались присвоить себе монопольное право интерпретации этих текстов. Эти институции, тем не менее, способствовали распространению самих текстов и гуманистических идей, благодаря чему влияние этих текстов теперь стало глобальным.

\section{Humanistlike baastekstide kontseptsioonist}

Selle kontseptsiooni kohaselt on humanistlikud baastekstid olnud viimase paari aastatuhande jooksul ajalookulu suurimateks mõjutajateks. Need tekstid, mida ei ole kuigi palju, kujunesid Vana Maailma mitmes piirkonnas (Hiinas, Indias, Lähis-Idas) kindlal ajalooperioodil, mida võib mõningase üldistusena piiritleda-IV ja +II sajandiga.

Mõiste 'baastekst' tähendab teksti, mis tekstigeneraatorina on olnud aluseks üha uutele tekstidele. Humanistlikel baastekstidel on eriline suunitlus, mida väljendab sõna 'humanistlik'. Neid iseloomustab ühelt poolt inimese kui niisuguse (liigi ja üksikisiku) ülendamine olemasolu keskseks ja määravaks nähtuseks, teiselt poolt aga niisuguste "inimlike" omaduste rõhutamine, nagu väärikus, inimarmastus, kaastunne, vägivallatus, vastutustunne, kohusetunne, aupaklikkus jne. 
Kuigi iga humanistlik baastekst on kujunenud oma kultuuri kontekstis, mille mõju on avaldunud nii sisu kui ka vormi eripäradena, on kõigis neis sarnasusi ja ühiseid jooni piisavalt palju. Need puudutavad peamiselt kolme valdkonda: (A) tekstide kujunemisprotsessi ja ülesehitust, (B) nendes esitatud õpetusi ning (C) nende vahetut ja kaudset mõju.

(A) Kõik need tekstid esitavad kindlat Õpetust ja lähtuvad kindlalt Õpetajalt. Õpetajad kuulutasid oma õpetust suuliselt, see pandi kirja tema õpilaste ja järeltulijate poolt ning võttis pikas redigeerimisprotsessis lõpuks kanoonilise kuju.

(B) Iga humanistliku baasteksti õpetus on vormilt, sisult ja ka terminoloogiliselt seotud kindla kultuurikeskkonnaga, mille raames see kujunes. Samas on inimene humanistlike baastekstide seisukohalt kultuurikeskne olend, kes mitte ainult ei sõltu kultuuri hetkeseisust ega ole kultuuri taastootja, vaid ka kultuuri looja. Humanistlike baastekstide eesmärgiks on näidata inimesele tema olemasolu mõtet ja seda, mis on tema võimalused ja ülesanded mitte üksnes füüsilises maailmas, vaid ka antud hetkel antud kohas valitsevas ühiskonna- ja kultuurisituatsioonis; teha inimesele selgeks, et tema kui inimsoo liige ja konkreetne isiksus (kuid mitte ego) on maailmas midagi erakordset, mille tõttu ta saab ja peab täie vastutustundega toimima.

(C) Humanistlike baastekstide dialoogis taustkultuurikeskkonnaga hakkas nende mõju ühiskonnas pikkamööda suurenema, eriti peale kanooniliste tekstide väljakujunemist. Nende põhjal tekkis religioosseid, filosoofilisi ja muid õpetusi, aga ka institutsioone, mis sageli püüdsid endale omistada tekstide interpreteerimise ainuõigust. Eeskätt just need institutsioonid on aga aidanud kaasa tekstide endi ja humanistlike ideede levikule, tänu millele nende mõju on nüüdseks saavutanud globaalse ulatuse. 